local open access spirometry service rather than buy a spirometer. Only $11 \%$ of practices surveyed currently have this service available. Thus, there will need to be a major expansion in open access services, which will have corresponding cost implications for secondary care equipment and staffing levels.

Our results indicate that steroid challenge tests are performed infrequently and for an inadequate time period. It is known that patients who respond to inhaled bronchodilators do not necessarily respond to inhaled steroids, and therefore many patients are prescribed these drugs inappropriately. ${ }^{6}$ Patients with moderate to severe COPD warrant a formal trial of corticosteroids, for example prednisolone $30 \mathrm{mg}$ daily for at least two weeks. Patients who respond with an increased $\mathrm{FEV}_{1}$ of more than $200 \mathrm{ml}$ will benefit from taking inhaled steroids long-term.

We accept the inherent problem of enthusiast bias in the case of postal questionnaires; individuals with a personal interest in respiratory disease are more likely to respond. This might explain the unexpectedly high figure for spirometer use found in this random sample of GPs. However, this survey probably denotes current best practice in spirometry usage within primary care.

Spirometry is the most appropriate investigation in COPD. It may also allow more effective screening of asymptomatic smokers with the major incentive of preventing disease. Over a period of time reduced smoking could result in savings in hospital care and time off work, but may also help to reduce morbidity from cardiovascular disease.
CONCLUSION Table 2: Reversibility testing

Spirometry is under-used in general practice and many GPs would prefer to use a hospital open access service rather than

buy a spirometer.

This implies an increased

\begin{tabular}{|c|c|c|c|}
\hline & $\begin{array}{c}\text { GPIAG } \\
\text { Members } \\
n=349\end{array}$ & $\begin{array}{c}\text { Random } \\
\text { Group } \\
n=582\end{array}$ & $\begin{array}{c}\text { Total } \\
n=931\end{array}$ \\
\hline \multirow{2}{*}{$\begin{array}{l}\text { Routine use of bronchodilator } \\
\text { reversibility for:- } \\
\text { Asthma } \\
\text { COPD } \\
\text { Standard dose of bronchodilator }\end{array}$} & 280 (80\%) & 484 (83\%) & 764 (82\%) \\
\hline & $\begin{array}{l}270(96 \%) \\
220(79 \%) \\
204(73 \%)\end{array}$ & $\begin{array}{l}471(97 \%) \\
376(78 \%) \\
449(93 \%)\end{array}$ & $\begin{array}{l}741(97 \%) \\
596(78 \%) \\
653(85 \%)\end{array}$ \\
\hline \multirow{3}{*}{$\begin{array}{l}\text { Routine use of oral steroid } \\
\text { reversibility for:- } \\
\text { Asthma } \\
\text { COPD } \\
\text { Dose of prednisolone above } \\
30 \mathrm{mg} / \mathrm{day} \\
\text { Test lasts }<14 \text { days }\end{array}$} & 152( & $156\left(27^{\circ}\right.$ & $308\left(33^{\circ}\right.$ \\
\hline & $\begin{array}{r}87(57 \%) \\
133(88 \%) \\
135(89 \%)\end{array}$ & $\begin{array}{l}109(70 \%) \\
123(79 \%) \\
138(88 \%)\end{array}$ & $\begin{array}{l}196(64 \%) \\
256(83 \%) \\
273(89 \%)\end{array}$ \\
\hline & 57 (38\%) & $105(67 \%)$ & $162(53 \%)$ \\
\hline
\end{tabular}

need for training and expansion of hospital spirometry services in the future.

Conflict of interest: None.

Funding: This study was supported by an educational grant from Glaxo Wellcome.

\section{References}

1. British Thoracic Society guidelines on COPD (1997 in press).

2. ERS - Consensus Statement. Optimal assessment and

management of chronic obstructive pulmonary disease (COPD).

Eur Respir J 1995; 8: 1398-420.

3. Quanjer P H, Tammeling G J, Cotes J E et al. Lung volumes and forced ventilatory flows. Eur Respir J 1993; 6 (S16): 5-40.

4. Fletcher C, Peto R. The natural history of chronic airflow obstruction. BMJ 1977; 1: 1645-8.

5. Office of Population Censuses \& Surveys Mortality Statistics,

Cause: England \& Wales 1992; Series DH@No 19. HMSO,

London, 1993

6. Dow 1, Coggon D, Holgate S T. Respiratory symptoms as predictors of airways lability in the elderly population. Respir Med 1992; 86: 27-32.

\title{
Is childhood pneumonia an unrecognised presentation of asthma?
}

\author{
C E Clark
}

AbSTRact

Background: Personal experience suggests that some children presenting with pneumonia may have undiagnosed asthma.

Objective: To determine the frequency with which asthma is diagnosed following pneumonia.

Method: Retrospective review of the hospital records of 99 children, aged under 17 years, admitted to hospital with pneumonia.

Results: Twenty eight per cent of the children were asthmatic; one third of these (i.e. nine per cent of patients) were newly diagnosed in the six weeks following discharge. Asthmatics were older than the non-asthmatics presenting with pneumonia, and were more likely to have a family history of asthma or personal history of atopy.

Conclusion: Routine follow-up of children admitted with pneumonia can identify new cases of asthma and a high index of suspicion is recommended.

\section{INTRODUCTION}

Asthma is a common childhood disorder. Episodic wheeze and cough at night have been documented as markers of asthma. ${ }^{1}$ However, $25 \%$ of asthmatics do not wheeze prior to diagnosis ${ }^{2}$ and this may lead to delays in diagnosis. ${ }^{3}$ Asthma has been under-diagnosed in children ${ }^{4}$ and recognition of markers other than wheeze ${ }^{5}$ (see Table 1), may help to remedy this. Our clinical experience has shown that young asthmatic patients are sometimes diagnosed following an episode of pneumonia and we considered that pneumonia itself may be a marker for undiagnosed asthma. Little in the available literature directly addresses this hypothesis, so the following pilot study was undertaken to establish how often asthma is diagnosed shortly after an episode of pneumonia.

\section{MeTHOD}

We retrospectivly reviewed the hospital discharge records of all patients aged under 17 years, who had been admitted to the Royal Devon \& Exeter District Hospital (serving a population of 250000) with pneumonia between January 1989 and July 1991. Records were examined retrospectively for: age; sex;

\author{
Christopher Clark \\ Registrar \\ Department of Respiratory \\ Medicine, Royal Devon \& \\ Exeter Hospital (Wonford) \\ Barrack Road, Exeter \\ Devon EX2 5DW. \\ Correspondence to: \\ School Surgery, Fore Street, \\ Witheridge, Devon \\ EX16 8AH.
}

Asthma in Gen Pract 1997; 5(1): 9-11. 
Table 1: Clues to the diagnosis of asthma in childhood

\begin{tabular}{|c|c|c|}
\hline \multicolumn{2}{|l|}{ COMMON } & UNCOMMON \\
\hline $\begin{array}{l}\text { Family history: } \\
\text { - asthma } \\
\text { - eczema }\end{array}$ & $\begin{array}{l}\text { - allergies } \\
\text { - atopy }\end{array}$ & \multirow[t]{4}{*}{$\begin{array}{l}\text { - prodromal itching } \\
\text { - vomiting } \\
\text { - chest pain }\end{array}$} \\
\hline $\begin{array}{l}\text { Symptoms preci } \\
\text { - infections } \\
\text { - excitement } \\
\text { - cold weather } \\
\text { - animals }\end{array}$ & $\begin{array}{l}\text { pitated by: } \\
\text { - dust } \\
\text { - smoke } \\
\text { - pollen } \\
\text { - exercise }\end{array}$ & \\
\hline $\begin{array}{l}\text { Cough: } \\
\text { - night } \\
\text { - recurrent }\end{array}$ & $\begin{array}{l}\text { - dry/productive } \\
\text { - persists for a } \\
\text { long time }\end{array}$ & \\
\hline \multicolumn{2}{|c|}{$\begin{array}{l}\text { Wheeze } \\
\text { Disturbed nights } \\
\text { Exercise intolerance }\end{array}$} & \\
\hline
\end{tabular}

Source: Le in Practice. London, Royal College of General Practitioners, 1992, Table 4.1. Reproduced with permission.

admitting doctor had recorded this in the notes, with supporting clinical signs, such as focal crepitations, bronchial breathing or dullness to percussion. The written report of the chest radiograph from admission was read to confirm diagnosis.

Table 2: Reasons for exclusion from the study

\begin{tabular}{|c|c|c|}
\hline $\begin{array}{l}\text { Pneumonia secondary } \\
\text { to other causes }\end{array}$ & $\begin{array}{l}\text { Foreign body } \\
\text { Myocarditis } \\
\text { Prematurity }\end{array}$ & $\begin{array}{l}2 \\
1 \\
1\end{array}$ \\
\hline $\begin{array}{l}\text { Diagnosis other than } \\
\text { pneumonia: }\end{array}$ & $\begin{array}{l}\text { Viral pneumonia } \\
\text { Bronchiolitis }\end{array}$ & $\begin{array}{l}2 \\
1\end{array}$ \\
\hline $\begin{array}{l}\text { No documented evidence } \\
\text { of pneumonia in notes: }\end{array}$ & & 2 \\
\hline TOTAL & & 9 \\
\hline
\end{tabular}

Figure 1: Age distribution

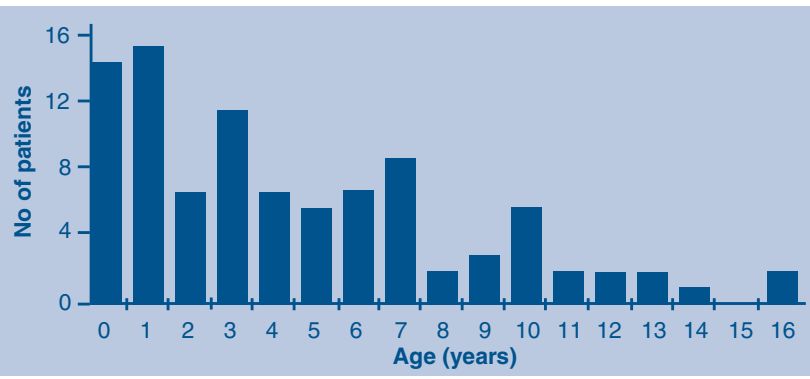

for significance by Yates corrected Chi square, or

Fisher's exact test if an expected value was less than five.

The data were stored and analysed using an epidemiological software and statistical package (Epi-Info v5.0). ${ }^{6}$ Means were compared by Kruskal-Wallis test for two groups, Odds ratios (ORs) were calculated from single table analyses with

Cornfield 95\% confidence intervals (c.i.), and tested

\section{RESUlts}

One hundred and fifty two cases of pneumonia were identified and reviewed. Twelve children with mental handicap (one deceased) were excluded from the study as this was considered an independent risk factor for pneumonia, e.g. secondary to feeding disorders. Further follow-up of these children may also have been difficult

Nine other children were excluded from the study (see Table 2) leaving 131 cases of community-acquired pneumonia.

For this pilot study, ethical approval was confined to those children followed-up in hospital; permission was not given for contact with general practitioners. This excluded a further 32 children from the study. The remaining 99 children (59 males) formed the study group. No significant differences were demonstrated in any of the parameters listed under 'Method' (above) between children followed-up in hospital or at home.
The mean age of the study group was 4.5 years (standard deviation 4.05; range $0-16$ years) and 38\% were aged two or under (see Fig 1). The mean duration of admission was 4.5 days (standard deviation 2.18; range $0-13$ nights). Nineteen patients in the study (19\%) had a diagnosis of asthma before the onset of their pneumonia. Mean follow-up was at six weeks after discharge and at this visit 14 children without a previous diagnosis of asthma still had symptoms of cough or wheeze. Nine of these were subsequently diagnosed as asthmatic. Thus, a total of 28 study group children $(28 \%)$ were asthmatic of whom one third were newly diagnosed as such in the six weeks following hospital admission for pneumonia.

Children with asthma were older than their non-asthmatic peers (mean age 5.6 vs 4.1 years; mean difference 1.5 years; $95 \%$ c.i. 0 to 3.2 years; $\mathrm{p}=0.03$ ) and showed a higher incidence of atopy ( $32 \%$ vs $10 \%$; OR 4.3 ; $95 \%$ c.i. 1.24 to $15.38 ; \mathrm{p}=0.01)$, and positive family history of asthma in a first degree relative (59\% vs $15 \%$; OR 7.27 ; $95 \%$ c.i. 2.4 to $22.4 ; \mathrm{p}=0.00008)$.

Spirometry was performed during admission in only four children, all of whom had previously been diagnosed as asthmatic. Nine children, eight of whom were existing asthmatics, were tested at follow-up. None of the new diagnoses were supported by spirometry.

\section{Discussion}

Nine per cent of the study group were newly diagnosed as asthmatic in the six-week period following their pneumonia. Nine of the 28 asthmatic children admitted with pneumonia were first diagnosed in the six weeks after discharge, suggesting a possible relationship between pneumonia and previously undiagnosed asthma.

This study does not determine whether the pneumonia was the result of undiagnosed asthma or, in fact, caused the subsequent symptoms. Middle lobe or lingula collapse can occur in asthmatics and is often associated with bacterial infection. ${ }^{7}$ In addition, increased airway reactivity can be detected several years before the clinical onset of asthma, ${ }^{8}$ thus the potential exists for pneumonia to develop before asthma is diagnosed.

Pneumonia by the age of seven has also been independently associated with asthma in a large prospective cohort study, ${ }^{9}$ with an OR of 4.24 in the two to seven age group and 2.0 in those under two, which appears to be consistent with our findings in the older age group. In the cohort study, ${ }^{9}$ the association between pneumonia and asthma was no longer significant during longer follow-up at ages 17 to 33 years; no causal link was suggested.

Impaired lung function and bronchial hyperreactivity (BHR) are much more common after infantile pneumonia than is asthma. An eight year follow-up of 29 children with pneumonia revealed BHR in $45 \%$, but asthma in only $7 \% .{ }^{11}$ A previous case control study of 51 infants with pneumonia showed an increase in cough and wheeze, greatest in the year or two following the illness, and a nonsignificant increase in asthma after seven years. ${ }^{12}$ BHR could account for the results presented here, but the older age of the asthmatic children, and higher incidence of atopy and family history of asthma, are more in keeping with asthma. 
This was a retrospective study and the results are, therefore, dependent on the quality of information in the notes studied. There may have been recall bias of atopic and family history in known asthmatics, but this would seem less likely in the cases only subsequently diagnosed as asthmatic. The numbers were also limited, by ethical constraints, to those children followed-up within the hospital. It is possible that these were more severely ill, but no significant differences were demonstrated between those followed-up in hospital or at home. A further six-year follow-up of all 131 potential cases is under way to overcome this, and also to differentiate between BHR, which declines with time, and asthma. On the basis of these preliminary results, however, it seems reasonable to suggest that children admitted with pneumonia are followed-up about six weeks later with a high index of suspicion for asthma, particularly if there is a family history of asthma and a personal history of atopy. In this study a quarter of the original cohort were left to follow-up in general practice, and it might be expected that another two or three cases of asthma would be diagnosed among them.

\section{CONCLUSION}

This study suggests that careful follow-up of children after an episode of pneumonia may be useful in determining previously undiagnosed cases of asthma. A prospective study may be useful.

\section{Acknowledgements}

I wish to thank Dr Alex Ferguson for his inspiration and support for this work, and my wife Karen for her tolerance during it.

\section{Conflict of interest: None}

Funding: None.

\section{References}

1. Turner-Warwick M. Nocturnal asthma: a study in general practice. J R Coll Gen Pract 1989; 39: 239-43.

2. Levy M, Bell M. General practice audit of asthma in childhood. BMJ 1984; 289:1115-6.

3. Jones A, Sykes A. The effect of symptom presentation on delay in asthma diagnosis in children in a general practice. Respir Med 1990; 84: $139-42$

4. Speight A N P, Lee D A, Hey E N. Underdiagnosis and undertreatment of asthma in childhood. BMJ 1983; 286: 1253-6.

5. Levy M and Hilton S. Asthma in Practice. Exeter, Royal College of General Practitioners, 1992 (2nd ed); 17.

6. Dean A G, Dean J A, Burton A H et al. Epi-Info, Version 5: a word processing, database, and statistics program for epidemiology on microcomputers. Stone Mountain, US, USD Inc, 1990.

7. Springer C, Avital A, Noviski N et al. Role of infection in middle lobe syndrome in asthma. Arch Dis Child 1992; 67: 592-4.

8. Hopp R J, Townley R G, Biven R E et al. The presence of airway reactivity before the onset of asthma. Am Rev Respir Dis 1990; 141: $2-8$

9. Strachan D P, Butland B K, Anderson H R. Incidence and prognosis of asthma and wheezing illness from early childhood to age 33 in a national British cohort. BMJ 1996; 312: 1195-9.

10. Gold D R, Tager I B, Weiss S T et al. Acute lower respiratory illness in childhood as a predictor of lung function and chronic respiratory symptoms. Am Rev Respir Dis 1989; 140: 877-84.

11. Korppi M, Kuikka L, Reijonen T et al. Bronchial asthma and hyperreactivity after early childhood bronchiolitis or pneumonia. Arch Pediatr Adolesc Med 1994; 148: 1079-84.

12. Mok JY Q and Simpson H. Outcome for acute bronchitis, bronchiolitis and pneumonia in infancy. Arch Dis Child 1984; 59: 306-9.

13. Camilli A E, Holberg C J, Wright A L et al. Parental childhood respiratory illness and respiratory illness in their infants. Pediatric Pulmonology 1993; 16: 275-80

\title{
How do patients operate self-management plans?
}

\author{
M E Hyland
}

ABSTRACT

Objective: To examine the extent to which patients are empowered by their doctor or nurse to adjust their asthma medication dose using self-management plans.

Method: $\quad$ A small survey was undertaken among 114 asthma patients (from 14 practices) on regular maintenance inhaled steroid therapy. Patients were asked to complete an anonymous questionnaire about the instructions they had been given and their use of their steroid inhaler.

Results: $\quad$ Seventy seven per cent of the 114 asthmatics in the survey would increase their 'brown' inhaler if their symptoms got worse and $40 \%$ would reduce their 'brown' inhaler if they had no symptoms. On the whole, the patients' description of their selfmanagement plans reflected the reported advice given by the doctor/nurse, although there was evidence of some intentional non-compliance. Most notably, $17 \%$ reported that they would stop using their 'brown' inhaler if they had no symptoms.
Conclusion: Younger patients were empowered to manage their asthma more than older patients. Patients are more likely to be advised to step up their prophylactic therapy during uncontrolled episodes, rather than to step down when their asthma comes under control. Although the majority of patients reported that they followed the instructions they were given, a significant minority reported deliberate non-compliance with the use of prophylactic treatment.

\section{INTRODUCTION}

Self-management plans (SMPs) have been an accepted part of asthma management for many years, ${ }^{1}$ and the principle that 'patients or parents should be enabled to manage their own treatment rather than be required to consult the doctor before making changes' is integral to the British Thoracic Society guidelines for asthma management. $^{2-4}$

However, SMPs can vary in the degree of control given to the patient. Consider the following three approaches to management:

\section{Michael Hyland \\ Professor of Health Psychology}

Correspondence to: Department of Psychology, University of Plymouth, Plymouth PL4 8AA.

Asthma in Gen Pract 1997; 5(1): 11-13. 